Volume. 8 Nomor. 2, Mei 2021. p - 2354-8649 I e - 2579-5767

Open Access at: http://ojs.umrah.ac.id/index.php/selat

DOI: https://doi.org/10.31629/selat.v8i2.3134

\title{
PROBLEMATIKA KEJAKSAAN NEGERI PEKANBARU DALAM MENGEKSEKUSI UANG PENGGANTI TERPIDANA TINDAK PIDANA KORUPSI
}

\author{
Tri Novita Sari Manihuruk \\ Fakultas Hukum Universitas Lancang Kuning \\ Jl. Yos Sudarso KM, Rumbai Pekanbaru \\ trinovitasarimanihuruk93@gmail.com
}

\begin{abstract}
The criminal execution of paying replacement money becomes a problem when the prosecutor as the executor will carry out the execution. The facts on the ground show that many convicts do not pay replacement money. The problems of the Pekanbaru District Attorney's Office in carrying out the execution of replacement money for convicted criminal acts of corruption are: First, the convict does not pay the replacement money charged to him; and the convict does not have sufficient property to pay the replacement money. Second, there is no synergy between the Ministry of Finance and the Pekanbaru District Attorney if the convict does not pay the replacement money. The efforts of the Pekanbaru District Prosecutor's Office in Executing Replacement Money Against Corruption Convicts, namely asset tracing (asset tracking), and increasing synergy between the Ministry of Finance and the Pekanbaru District Attorney if the convict does not pay the replacement money.
\end{abstract}

Keywords; Prosecutor, Substitue Money Execution, Corruption Crime

\begin{abstract}
Abstrak
Eksekusi pidana pembayaran uang pengganti menjadi masalah saat jaksa selaku eksekutor akan melakukan eksekusi. Fakta dilapangan menunjukkan bahwa banyaknya terpidana yang tidak membayar uang pengganti. Problematika Kejaksaan Negeri Pekanbaru dalam pelaksanaan Eksekusi Uang pengganti terhadap terpidana tindak pidana korupsi yaitu: Pertama, terpidana tidak membayar uang pengganti yang dibebankan kepadanya; dan terpidana tidak mempunyai harta benda yang mencukupi untuk membayar uang pengganti. Kedua, Belum ada sinergitas antara Kementerian Keuangan dengan Kejaksaan Negeri Pekanbaru apabila terpidana tidak membayar Uang Pengganti. Upaya Kejaksaan Negeri Pekanbaru dalam Mengeksekusi Uang Pengganti Terhadap Terpidana Tindak Pidana Korupsi yaitu dilakukan asset tracing (pelacakan aset), dan meningkatkan sinergitas antara Kementerian Keuangan dengan Kejaksaan Negeri Pekanbaru apabila terpidana tidak membayar Uang Pengganti.
\end{abstract}

Kata kunci; Kejaksaan, Eksekusi Uang Pengganti, Tindak Pidana Korupsi. 


\section{PENDAHULUAN}

Tindak pidana korupsi merupakan bentuk tindak pidana yang dapat dikategorikan sebagai permasalahan nasional yang harus dihadapi secara serius dengan cara menjalankan langkah langkah yang tegas dan benar, sekaligus melibatkan semua potensi yang ada dalam masyarakat khususnya pemerintah dan aparat penegak hukum. Tindak pidana korupsi juga dikategorikan sebagai salah satu kejahatan luar biasa (extra ordinary crime) karena tindak pidana korupsi merupakan perbuatan yang sangat merugikan keuangan negara dan masyarakat, sehingga dapat menghambat jalannya pembangunan nasional. ${ }^{1}$

Salah satu unsur dalam tindak pidana korupsi ialah adanya kerugian keuangan negara. Terhadap kerugian keuangan negara ini, pemerintah membuat UndangUndang Nomor 3 Tahun 1971 jo. Undang-Undang Nomor 31 Tahun 1999 jo. UndangUndang Nomor 20 Tahun 2001 UUPTPK, yang selanjutnya disebut UndangUndang Tentang Pemberantasan Tindak Pidana Korupsi, menetapkan kebijakan bahwa kerugian keuangan negara itu harus dikembalikan atau diganti oleh pelaku korupsi.

Keharusan untuk mengembalikan kerugian keuangan negara tersebut secara formal sudah di atur dalam UU Tipikor, Pasal 18 ayat (1) huruf b Undang-Undang Nomor 31 Tahun 1999 Tentang Pemberantasan Tindak Pidana Korupsi menegaskan bahwa "Pembayaran uang pengganti yang jumlahnya sebanyak-banyaknya sama dengan harta benda yang diperoleh dari tindak pidana korupsi”. Aturan ini dikaji dari segi kebijakan politik hukum pemberantasan korupsi adalah sebuah kemajuan karena menunjukan adanya kemauan negara untuk mengembalikan uang negara yang hilang/berkurang akibat tindak pidana korupsi. Tetapi Pasal 18 ayat (3) menyebutkan bahwa: Dalam hal terpidana tidak mempunyai harta benda yang mencukupi untuk membayar uang pengganti sebagaimana dimaksud dalam ayat (1) huruf $b$, maka dipidana dengan pidana penjara yang lamanya tidak melebihi ancaman maksimum dari pidana pokoknya sesuai ketentuan dalam undang-undang ini dan lamanya pidana tersebut sudah ditentukan dalam putusan pengadilan. Aturan ini

\footnotetext{
${ }^{1}$ I. Muh. Adenriz Yunus, Diana Lukitasari, “Optimalisasi Esekusi Pidana Uang Pengganti Melalui Pembentukan Satuan Kerja Khusus (Studi Kasus Di Kejaksaan Negeri Surakarta,)” Recidive, September-Desember 2019: Vol. 8, No. 3, hlm. 3.
} 
menimbulkan problem yuridis karena satu sisi memiliki semangat pemulihan aset melalui kebijakan uang pengganti tetapi di pihak lain memberikan peluang bagi terpidana untuk memilih membayar uang pengganti atau menjalani pidana subsider. ${ }^{2}$

Pembayaran uang pengganti sebagai pidana tambahan yang diputuskan kepada pelaku tindak pidana korupsi pada hakekatnya adalah sebagai upaya untuk mengembalikan kerugian keuangan negara yang diakibatkan oleh tindak korupsi. Mengutip pendapat Andi Hamzah bahwa uang pengganti adalah merupakan sejumlah uang yang dibebankan kepada pelaku tindak pidana korupsi dengan jumlah uang yang pernah ia korupsikan yang jumlahnya sebanyak-banyaknya sama dengan harta benda yang diperoleh dari korupsi tersebut1, maka pidana tambahan pembayaran uang pengganti perlu dituntut dan diputuskan pada setiap kasus tindak pidana korupsi sebagai salah satu upaya dari aparat penegak hukum untuk mengembalikan kerugian keuangan negara. ${ }^{3}$

Penerapan uang pengganti yang telah berlaku terbukti belum efektif mengupayakan pengembalian kerugian keuangan negara secara optimal karena pengaturan pengembalian kerugian keuangan negara melalui ketentuan uang pengganti dalam undang-undang tersebut belum memenuhi tujuan hukum. Menyadari kompleksnya permasalahan korupsi maka pemberantasannya harus dilakukan dengan cara yang tegas dengan melibatkan semua potensi yang ada dalam masyarakat khususnya Pemerintah dan Aparat penegak hukum. ${ }^{4}$

Eksekusi pidana pembayaran uang pengganti yang mengalami kendala ini tentu merugikan keuangan negara, terlebih lagi para terpidana korupsi ini tidak mengalami efek jera, karena ketika sudah di jatuhi pidana oleh hakim mengenai pidana pembayaran uang pengganti mereka justru tidak membayar dan menjadi tunggakan di Kejaksaan.

Pidana Pengganti (subsidair) inilah yang menjadi masalah pada saat jaksa eksekutor akan melakukan eksekusi. Pidana Pengganti (subsidair) menjadi peluang

\footnotetext{
2 Ade Mahmud, "Dinamika Pembayaran Uang Pengganti Dalam Tindak Pidana Korupsi)”. Jurnal Hukum. Mimb. Justitia, Desember 2017: Vol. 3, No 2, hlm. 139.

3 Kejaksaan Agung. Optimalisasi Penyelesaian Tunggakan Uang Pengganti Yang Diputus Berdasarkan UndangUndang Nomor 3 Tahun 1971 Tentang Pemberantasan Tindak Pidana Korupsi. Jakarta: Miswar, 2016, hlm. 1

${ }^{4}$ M. M. Mohamad Ginanjar, Dahlan Ali, "Eksekusi Uang Pengganti terhadap Terpidana Korupsi oleh Kejaksaan Tinggi Aceh," Kanun Jurnal Ilmu Hukum, Agustus 2016: Vol. 18, № 2, hlm. 320
} 
bagi para terpidana korupsi untuk menghindari pembayaran pidana uang pengganti. Para Koruptor cenderung lebih banyak memilih menggantinya dengan pidana pengganti yang lamanya maksimal 6 bulan apabila merujuk pada pasal 30 KUHP. Pada akhirnya Putusan Pengadilan Tipikor menjatuhkan pidana pembayaran uang pengganti untuk mengembalikan kerugian keuangan Negara menjadi sia-sia karena pidana pengganti menjadi celah bagi para terpidana korupis untuk mengamankan harta hasil Korupsi. Hal inilah yang menjadi akar permasalahan bagi Jaksa Eksekutor ketika akan melakukan eksekusi pembayaran uang pengganti untuk menutupi kerugian Negara/perekonomian Negara atau memulihkan kembali kerugian Negara yang dibebankan kepada terpidana korupsi. ${ }^{5}$

Fakta dilapangan masih menunjukkan bahwa terhadap Terpidana Korupsi seringkali diberikan Pidana Tambahan berupa pembayaran uang pengganti sebagai konsekuensi pengembalian kerugian keuangan Negara, seperti yang terjadi di Pekanbaru. Berikut data mengenai Uang Pengganti Tindak Pidana Korupsi di Kejaksaan Negeri Pekanbaru.

\section{Tabel 1.1}

Data Uang Pengganti Tindak Pidana Korupsi di Kejaksaan Negeri Pekanbaru

\begin{tabular}{|c|c|c|c|c|c|c|}
\hline \multirow{3}{*}{ No } & \multirow{3}{*}{$\begin{array}{l}\text { Nama } \\
\text { Terpidana }\end{array}$} & \multirow{3}{*}{$\begin{array}{l}\text { Putusan } \\
\text { Pengadilan }\end{array}$} & \multirow{3}{*}{$\begin{array}{l}\text { Tanggal } \\
\text { Putusan }\end{array}$} & \multicolumn{3}{|c|}{ Hukuman } \\
\hline & & & & \multirow{2}{*}{$\begin{array}{l}\text { Pidana } \\
\text { Badan }\end{array}$} & \multicolumn{2}{|c|}{ Jumlah Uang Pengganti } \\
\hline & & & & & Rupiah & Subsider \\
\hline 1 & ASNIL. ST. M.Si & $\begin{array}{l}\text { 51/PID.SUS- } \\
\text { TPK/2017 }\end{array}$ & $\begin{array}{c}06 / 11 / 201 \\
7\end{array}$ & $\begin{array}{c}1 \mathrm{TH} 4 \\
\text { BLN }\end{array}$ & Rp 79.769.000 & $1 \mathrm{TH}$ \\
\hline 2 & $\begin{array}{l}\text { DECY ARI } \\
\text { YETTI }\end{array}$ & $\begin{array}{c}\text { 15/PID.SUS- } \\
\text { TPK/2018 }\end{array}$ & $\begin{array}{c}23 / 08 / 201 \\
8\end{array}$ & $\begin{array}{c}\text { 1THN } 4 \\
\text { BLN }\end{array}$ & Rp 207.170.000 & $1 \mathrm{THN}$ \\
\hline 3 & $\begin{array}{l}\text { YULIANA J. } \\
\text { BASKORO }\end{array}$ & $\begin{array}{c}\text { 21/PID.SUS- } \\
\text { TPK/2018 }\end{array}$ & $\begin{array}{c}03 / 09 / 201 \\
8\end{array}$ & $3 \mathrm{THN}$ & Rp 755.357.543 & $6 \mathrm{BLN}$ \\
\hline 4 & $\begin{array}{l}\text { RENDI } \\
\text { HERMAWAN }\end{array}$ & $\begin{array}{c}\text { 50/PID.SUS/ } \\
\text { TPK/2017.PN } \\
\text {.PBR }\end{array}$ & $\begin{array}{c}12 / 05 / 201 \\
7\end{array}$ & $2 \mathrm{TH}$ & Rp 398.767.700 & $3 \mathrm{BLN}$ \\
\hline 5 & $\begin{array}{l}\text { T. ISMAIL } \\
\text { YUSUF }\end{array}$ & $\begin{array}{c}704 \\
\text { K/Pid.Sus/20 } \\
14\end{array}$ & $\begin{array}{c}02 / 03 / 201 \\
5\end{array}$ & $4 \mathrm{THN}$ & Rp 191.891.576 & $1 \mathrm{THN}$ \\
\hline 6 & $\begin{array}{l}\text { DEKI } \\
\text { BERMANA }\end{array}$ & $\begin{array}{c}2621 \\
\text { K/Pid.Sus/20 } \\
15\end{array}$ & $\begin{array}{c}24 / 08 / 201 \\
6\end{array}$ & 7 THN & Rp 547.137.000 & $2 \mathrm{THN}$ \\
\hline 7 & $\begin{array}{l}\text { HENDY } \\
\text { WIJAYA }\end{array}$ & $\begin{array}{c}2831 \\
\text { K/Pid.Sus/20 } \\
18\end{array}$ & $\begin{array}{c}17 / 01 / 201 \\
9\end{array}$ & 4 THN & Rp 120.000.000 & $\begin{array}{l}1 \text { THN } 6 \\
\text { BLN }\end{array}$ \\
\hline 8 & SYAHRONI & 52/Pid.Sus.T & $20 / 02 / 201$ & 1 THN 4 & Rp. 50.000.000 & $1 \mathrm{BLN}$ \\
\hline
\end{tabular}

5 Rudi Pardede. Proses Pengembalian Kerugian Negara Akibat Korupsi. Yogyakarta: Genta Publishing, 2016, hlm. 116 


\section{PEMBAHASAN}

\subsection{Problematika Kejaksaan Negeri Pekanbaru dalam Melaksanakan Eksekusi Uang Pengganti Terpidana Tindak Pidana Korupsi}

Salah satu persoalan mendasar yang sangat penting serta menjadi perhatian lebih mendalam dalam pemberantasan korupsi saat ini adalah bagaimana mengembalikan kerugian negara yang hilang sebagai akibat dilakukannya perbuatan korupsi, baik itu dilakukan oleh perorangan maupun korporasi. Penyelamatan uang serta asset negara ini menjadi penting untuk dilakukan, mengingat ada fakta dan fenomena yang terjadi selama ini bahwa pemberantasantindak pidana korupsi yang dilakukan hanya bisa menyelamatkan 10-15 persen saja dari total uang yang dikorupsi. Sebagai salah satu instrument hukum pidana yang memungkinkan penyelamatan uang negara dari perbuatan korupsi, instrumen hukum ini dianggap lebih rasional untuk mencapai tujuan pemberantasan korupsi, yakni mencegah kerugian negara. ${ }^{8}$

Pidana uang pengganti merupakan salah satu instrumen hukum yang digunakan dalam persoalan kerugian negara yang diakibatkan oleh tindak pidana korupsi sebagaimana Pasal 18 Undang-Undang Nomor 31 Tahun 1999 sebagaimana telah diubah dengan Undang-Undang Nomor 20 Tahun 2001 tentang Pemberantasan Tindak Pidana Korupsi. Undang-undang tersebut merupakan suatu instrumen hukum, dimana hukum menetapkan apa yang harus dilakukan dan apa yang boleh dilakukan serta yang dilarang. Sasaran hukum yang hendak dituju bukan saja orang yang nyatanyata berbuat melawan hukum melainkan juga perbuatan hukum yang mungkin akan terjadi dan kepada alat perlengkapan negara untuk bertindak menurut hukum dalam penyelenggaraan berbagai sektor pembangunan yang ternyata tidak hanya berdampak positif berupa pembangunan nasional dan kemajuan pada masyarakat secara umum akan tetapi juga terdapat dampak negatif terutama yang merupakan tindak pidana dan juga kejahatan yang fenomenal yaitu tindak pidana korupsi.

8 Guntur Rambey, "Pengembalian Kerugian Negara Dalam Tindak Pidana Korupsi Melalui Pembayaran Uang Pengganti Dan Denda, Jurnal Ilmu Hukum De Lega Lata.” Januari - Juni 2016: Vol. 1, No 1, hlm. 138. 
Tindak pidana ini tidak hanya merugikan terhadap keuangan negara tetapi juga hak-hak sosial dan ekonomi masyarakat. ${ }^{9}$ Kerugian negara semakin bertambah seiring dengan meningkatnya jumlah tindak pidana korupsi di Indonesia Berdasarkan ketentuan pidana pembayaran uang pengganti dalam UndangUndang Pemberantasan Tindak Pidana Korupsi sebetulnya kerugian negara dapat dikembalikan. Dalam hal ini Undang-Undang Pemberantasan Tindak Pidana Korupsi merupakan ketentuan yang dapat mengembalikan kerugian negara akibat tindak pidana korupsi, akan tetapi dalam pelaksanaannya pidana tambahan pembayaran uang pengganti harus dapat dilaksanakan semaksimal mungkin. Pidana tambahan uang pengganti dalam tindak pidana korupsi merupakan bentuk upaya pemidanaan terhadap mereka yang melakukan tindak pidana korupsi. Hal ini merupakan cara pengembalian kerugian keuangan negara dengan memberikan pemasukan ke kas negara dari hasil pembayaran uang pengganti para terpidana yang telah ditetapkan jumlah pembayaran uang penggantinya.

Selain itu faktor atau kendala lain yang terjadi dalam pelaksanaan pidana pembayaran uang pengganti adalah mengenai penegakan hukum, sarana atau fasilitas yang mendukung penegakan hukum, masyarakat, dan kebudayaan. Salah satu faktor yang menentukan proses penegakan hukum adalah tidak hanya pihakpihak yang menerapkan hukum tetapi juga pihak-pihak yang membuat hukum. Pihak-pihak dalam proses penegakan hukum yang dimaksud adalah kepolisian, kejaksaan, kehakiman, dan pengacara. Untuk dapat bekerja secara profesional, tentunya para aparat penegak hukum dihadapkan dengan berbagai problematika yang berbeda-beda ketika menjalankan tugas dan kewenangannya masing- masing Seperti yang terlihat dalam eksekusi oleh Kejaksaan Negeri Surakarta terhadap para terpidana korupsi. Ditemukan adanya problematika dalam melaksanakan eksekusi yang berasal dari aparat penegak hukum, yaitu Jaksa mengalami kesulitan dalam menemukan harta benda milik terpidana atau ahli waris yang kemungkinan dapat menimbulkan tunggakan uang pengganti yang sangat besar.

\footnotetext{
9 I. Munirah, "Pembayaran Pidana Uang Pengganti Dalam Perkara Korupsi," Kanun Jurnal Ilmu Hukum." Agustus 2017: Vol. 19, No 2, hlm. 346.
} 
Kesulitan Jaksa dalam menemukan harta benda milik terpidana karena faktor sarana atau fasilitas yang mendukung penegakan hukum. Tanpa adanya sarana atau fasilitas yang mendukung, maka penegakan hukum akan berjalan lamban. Sarana tersebut mencakup tenaga manusia yang berpendidikan dan terampil, organisasi yang baik, peralatan yang memadai dan keuangan yang cukup. Kesemuanya itu penting untuk mendukung keberhasilan penegakan hukum. Ditinjau dari faktor sarana dan prasarana yang dimiliki oleh Kejaksaan dalam menangani tindak pidana korupsi yang dilakukan oleh para terpidana, masih dihadapkan pada permasalahan keuangan. Anggaran dana tahunan yang dikucurkan dari pusat kepada Kejaksaan untuk penanganan perkara selama setahun belum mencukupi untuk mendukung pelaksanaan penegakan hukum. Penegakan hukum agar dapat dijalankan juga dipengaruhi oleh lingkungan dimana hukum tersebut berlaku atau diterapkan.

Berdasarkan hasil wawancara penulis dengan Bapak R.M Yusuf Trisna Jaya, SH., MH Selaku Kasubsi Penuntutan Pidana Khusus di Kejaksaan Negeri Pekanbaru pada hari Jumat, 21 Februari 2020 Jam 10.15 WIB diperoleh informasi bahwa, Berbagai hambatan yang dihadapi Jaksa selaku eksekutor dalam eksekusi pidana tambahan pembayaran uang pengganti, antara lain:

\section{a) Terpidana tidak membayar Uang Pengganti}

Jika dilihat dari judulnya, Terpidana tidak membayar uang pengganti. Hal ini dimungkinkan karena memang undang- undang memberikan kelonggaran bagi terpidana apabila tidak membayar uang pengganti. Sehingga jika melihat dari teori sbelumnya, maka hal ini merupakan faktor dari hukum itu sendiri, dalam hal ini adalah Undang-Undang Tipikor. Faktor hukumnya sendiri yang di dalam tulisan ini akan dibatasi pada peraturan perundangundangannya saja. dalam pelaksanaan eksekusi pidana pembayaran uang pengganti pada dasarnya juga merupakan masalah penegakan hukum. Hukum dapat mencerminkan nilai-nilai yang didasari dari hukum itu sendiri agar hukum atau perturan perundang-undangan tersebut dapat lebih efektif. Sehubungan hal tersebut, peraturan peraturan perundang-undangan yang berkaitan dengan efektivitas pidana pembayaran uang pengganti dalam tindak pidana korupsi adalah Undang-Undang No.31 Tahun 1999 tentang pemberantasan 
tindak pidana korupsi, maka dari faktor hukumnya sendiri telah memiliki dasar hukum yang kuat. Akan tetapi dalam ketentuan pidana tambahan yakni Pasal 18 ayat (3) Undang-Undang 31 Tahun 1999 memberikan celah hukum yang menyatakan bahwa dalam hal terpidana tidak mempunyai harta benda yang mencukupi untuk membayar uang pengganti maka dipidana dengan pidana penjara yang lamanya tidak melebihi ancaman pidana pokok sesuai dengan ketentuan dalam undang-undang ini dan ditentukan dalam putusan hakim.

Berdasarkan hasil wawancara penulis dengan Bapak Riski Salmon, SH di Kejaksaan Negeri Pekanbaru, diperoleh informasi bahwa sejumlah terpidana tidak membayar uang pengganti. Hal ini dikarenakan ketidakmampuan terpidana untuk membayar uang pengganti tindak pidana korupsi. Seperti pada Putusan PK (Peninjauan Kembali) Nomor 45 PK/Pid.Sus/2017, dalam amar putusan tersebut dinyatakan:

\section{E N G A D I L I}

1. Mengabulkan Permohonan Peninjauan kembali dari Pemohon Peninjauan Kembali/Terpidana: DU NUN Alias AGUAN alias ANUN tersebut;

2. Membatalkan Putusan Mahkmah Agung RI Nomor 514 K/Pid.Sus/2016, tanggal 17 Mei 2016 yang memperbaiki Putusan Pengadilan Tinggi Tindak Pidana Korupsi pada Pengadilan Tinggi Pekanbaru Nomor 18/PID.SUS.TPK/2015/PT.PBR, tanggal 09 November 2015 yang membatalkan Putusan Pengadilan Tindak Pidana Korupsi pada Pengadilan Negeri Pekanbaru Nomor 07/Pid.Sus-TPK/2015/PN.PBR tanggal 18 Juni 2015;

3. Mengadili Kembali menyatakan Terpidana DU NUN Alias AGUAN alias ANUN tersebut; telah terbukti secara sah dan menyakinkan bersalah melakukan tindak pidana "TURUT SERTA MELAKUKAN KORUPSI DAN PENCUCIAN UANG SECARA BERLANJUT"

4. Menjatuhkan pidana kepada Terpidana oleh karena itu dengan Pidana Penjara selama 15 (lima belas) tahun dan pidana denda sebesar Rp. 500.000.000,00 (lima Miliyar rupiah) dengan ketentuan apabila pidana denda tersebut tidak dibayar, maka kepada Terpidana dikenakan pidana pengganti berupa pidana kurungan selama 1(satu) tahun dan 4 (empat) bulan;

5. Menjatuhkan pidana tambahan kepada Terpidana untuk membayar Uang Pengganti sebesar Rp 72.452.269.000, 00 (Tujuh puluh dua Miliar Empat ratus lima puluh dua juta rupiah) diperhitungkan dengan hasil lelang dari barang bukti yang disita dan dirampas untuk Negara, jika terpidana tidak membayar Uang Pengganti paling lama dalam waktu 1 bulan sesudah putusan Pengadilan memperoleh kekuatan hukum tetap, maka harta 
bendanya dapat disita oleh Jaksa dan dilelang untuk menutupi uang pengganti dengan pidana penjara selama 5 tahun;

Data ini menunjukan bahwa dalam praktik pengembalian kerugian negara (asset recovery) tidak berjalan seperti yang menjadi harapan masyarakat luas, Undangundang pemberantasan tindak pidana korupsi menghendaki adanya pengembalian kerugian negara bukan hanya melakukan penghukuman terhadap pelaku. Pelaku lebih memilih tidak melunasi uang pengganti atau lebih memilih menggantinya dengan pidana penjara pengganti (subsider). Putusan di atas juga menunjukan pola ketidaksebandingan dalam menentukan uang pengganti.

Perbuatan korupsi yang secara riil merugikan keuangan negara hanya diganti dengan pidana penjara di bwah 1-3 (satu) tahun. Negara mengalami kerugian ekonomi yang cukup memprihatinkan dan akibat tersebut dirasakan langsung oleh masyarakat tetapi kesalahan itu hanya ditebus dengan pidana kurungan yang cukup ringan. Model pemidanaan ini cukup melukai rasa keadilan masyarakat luas. Padahal semestinya uang pengganti sebagai pidana tambahan dalam tindak pidana korupsi bisa menjawab harapan masyarakat agat koruptor bisa mengembalikan uang negara. Pidana uang pengganti memberikan manfaat yang besar jika penegak hukum mampu mengembalikannya melalui pidana uang pengganti.

Pidana uang pengganti memang diformulasikan sebagai pidana tambahan, sifatnya fakultatif hanya menambah sanksi pidana pokok. Penjatuhan uang pengganti sangat bergantung pada kebijaksanaan hakim dalam menilai bukti-bukti yang muncul dalam persidangan. Hakim memiliki kemerdekaan untuk menjatuhkan uang pengganti pada terpidana atau tidak, tetapi jika dalam proses pembuktian Penuntut Umum mampu menunjukan adanya kerugian negara yang riil dan pasti jumlahnya akibat tindak pidana korupsi maka pidana pokok yang bersifat fakultatif bisa menjadi wajib dijatuhkan. "Problemnya seperti telah disebutkan bahwa ketentuan Pasal 18 ayat (3) UU Pemberantasan Tindak Pidana Korupsi memberi ruang kepada hakim untuk mensubsiderkan yang berakibat pada lolosnya koruptor dari kewajiban membayar uang pengganti. Akibatnya negara tetap merugi dan korupsi indeks persepsi korupsi terus meningkat". 
b) Belum ada Sinergitas antara Kementerian Keuangan dengan Kejaksaan Negeri Pekanbaru Apabila Terpidana Tidak Membayar Uang Pengganti

Kejaksaan Negeri Pekanbaru akan berkoordinasi kepada Menteri Keuangan perihal Pembayaran uang pengganti. Apabila terpidana tidak membayar Uang Pengganti, maka akan dibuatkan Berita Acara Pelaksanaan Hukuman Pengganti. Namun, terdapat kendala yang dihadapi Kejaksaan Negeri Pekanbaru yaitu belum ada Sinergitas antara Kementerian Keuangan dengan Kejaksaan Negeri Pekanbaru Apabila Terpidana Tidak Membayar Uang Pengganti. Maksudnya adalah, bilamana terpidana tidak membayar Uang Pengganti, Kementerian Keuangan beranggapan Pihak Kejaksaan tidak menyetorkan Uang Pengganti tersebut. Karena Kementerian Keuangan hanya berpatokan pada salinan/ isi putusan pengadilan saja.

Seperti pada salah satu Putusan PK (Peninjauan Kembali) Nomor 45 PK/Pid.Sus/2017 , dalam amar putusan tersebut menyatakan: "Menjatuhkan pidana tambahan kepada Terpidana untuk membayar Uang Pengganti sebesar Rp 72.452.269.000, 00 (Tujuh puluh dua Miliar Empat ratus lima puluh dua juta rupiah) diperhitungkan dengan hasil lelang dari barang bukti yang disita dan dirampas untuk Negara, jika terpidana tidak membayar Uang Pengganti paling lama dalam waktu 1 bulan sesudah putusan Pengadilan memperoleh kekuatan hukum tetap, maka harta bendanya dapat disita oleh Jaksa dan dilelang untuk menutupi uang pengganti dengan pidana penjara selama 5 tahun"

Oleh karena Terpidana tersebut tidak membayar Uang Pengganti, maka Kementerian Keuangan menganggap Uang Pengganti sebesar Rp 72.452.269.000, 00 (Tujuh puluh dua Miliar Empat ratus lima puluh dua juta rupiah) adalah Piutang Kejaksaan Negeri Pekanbaru. Kementerian Keuangan Menganggap Uang pengganti tersebut masih tunggakan Jaksa. Padahal terpidana yang tidak mampu membayar Uang Penggantinya.

\subsection{Upaya Kejaksaan Negeri Pekanbaru dalam Mengeksekusi Uang Pengganti Terhadap Terpidana Tindak Pidana Korupsi} a. Pelacakan/ pengembalian Aset (Asset recovery) 
Permasalahan yang ditemui dalam pengembalian kerugian keuangan negara melalui penjatuhan sanksi pembayaran uang pengganti dalam tindak pidana korupsi meliputi; terpidana tidak membayar uang pengganti yang dibebankan kepadanya, dan terpidana tidak mempunyai harta benda yang mencukupi untuk membayar uang pengganti yang dibebankan kepadanya. ${ }^{10}$

Berdasarkan hasil wawancara penulis dengan Bapak R.M Yusuf Trisna Jaya, SH., MH Selaku Kasubsi Penuntutan Pidana Khusus di Kejaksaan Negeri Pekanbaru pada hari Jumat, 21 Februari 2020 Jam 10.15 WIB diperoleh informasi bahwa Jika setelah dilakukan penyitaan terpidana tetap tidak melunasi pembayaran uang pengganti yang dibebankan kepadanya, maka Jaksa wajib melelang harta benda milik terpidana tersebut selambat-lambatnya 3 (tiga) bulan setelah dilakukan penyitaan, di mana esensinya adalah untuk mengembalikan kerugian keuangan negara. Setelah dilakukan pelelangan terhadap harta benda milik terpidana, Jaksa akan menyetorkan hasil pembayaran ke Kas Negara untuk membayar uang pengganti si terpidana tersebut, kemudian mengirimkan tembusan berita acara pelelangan tersebut kepada Pengadilan Negeri yang mengadili perkara.

\section{b. Meningkatkan Sinergitas antara Kejari, Kejati, Kejagung dengan Kementerian Keuangan dalam Pelaporan Uang Pengganti}

Untuk mengatasi kendala ini, maka Pihak Kejaksaan Mulai dari Kejari, Kejati sampai Kejagung harus meningkatkan sinergitasnya dengan Menteri Keuangan. Caranya adalah dengan membuat Pelaporan secara berkala oleh Pihak Kejaksaan mengenai Pembayaran Uang Pengganti. Sehingga kedepannya, Kementerian Keuangan tidak lagi mengganggap Jaksa masih memiliki tunggakan hutang, perihal tidak dibayarnya pidana pengganti oleh Terpidana.

\section{KESIMPULAN}

Problematika Kejaksaan Negeri Pekanbaru dalam pelaksanaan Eksekusi Uang pengganti terhadap terpidana tindak pidana korupsi yaitu: Pertama, terpidana tidak membayar uang pengganti yang dibebankan kepadanya; dan terpidana tidak

10 J. K. Hafid Rahman, Indra, Agna Susila. "Pelaksanaan Pembayaran Uang Pengganti Dalam Tindak Pidana Korupsi." Jurnal Varia Justicia, Maret 2016: Vol. 12, No. 1, hlm. 95. 
mempunyai harta benda yang mencukupi untuk membayar uang pengganti yang dibebankan kepadanya. Kedua, Belum ada sinergitas antara Kementerian Keuangan dengan Kejaksaan Negeri Pekanbaru apabila terpidana tidak membayar Uang Pengganti. Upaya Kejaksaan Negeri Pekanbaru dalam Mengeksekusi Uang Pengganti Terhadap Terpidana Tindak Pidana Korupsi yaitu: Pertama, terhadap terpidana yang tidak membayar uang pengganti, maka Jaksa wajib melakukan penyitaan dan pelelangan terhadap harta benda yang dimiliki terpidana, dan menyetorkan hasil pelelangan ke Kas Negara; kemudian terhadap terpidana yang tidak mempunyai harta benda yang mencukupi untuk membayar uang pengganti, maka pelunasan tunggakan uang penggantinya dilakukan melalui tuntutan subsider pidana penjara, atau hukuman badan yang lamanya tidak melebihi ancaman maksimum dari pidana pokok dan sudah ditentukan dalam putusan pengadilan (subsidair uang pengganti). Kedua, Meningkatkan Sinergitas antara Kejari, Kejati, Kejagung dengan Kementerian Keuangan dalam Pelaporan Uang Pengganti. Caranya adalah dengan membuat Pelaporan secara berkala oleh Pihak Kejaksaan mengenai Pembayaran Uang Pengganti. Sehingga kedepannya, Kementerian Keuangan tidak lagi mengganggap Jaksa masih memiliki tunggakan hutang, perihal tidak dibayarnya pidana pengganti oleh Terpidana. Selanjutnya Kepada Penegak hukum, khususnya Jaksa kedepannya harus lebih optimal untuk melakukan pelacakan aset2 terpidana korupsi guna untuk mengembalikan kerugian keuangan negara. Oleh karena pemberantasan korupsi tidak hanya difokuskan pada upaya penghukuman Pelaku, namun juga harus meminimalkan kerugian negara melalui proses pengembalian asset (asset recovery) Kepada Kejari, Kejati, Kejagung untuk meningkatkan sinergitas dengan Kementerian Keuangan dalam hal Pelaporan Uang Pengganti. Caranya adalah dengan membuat Pelaporan secara berkala oleh Pihak Kejaksaan mengenai Pembayaran Uang Pengganti. Sehingga kedepannya, Kementerian Keuangan tidak lagi mengganggap Jaksa masih memiliki tunggakan hutang, perihal tidak dibayarnya. 


\section{DAFTAR PUSTAKA}

\section{Buku}

A. dan Z. Asikin, Pengantar Metode Penelitian Hukum. Jakarta: Raja Grafindo, 2003.

Kejaksaan Agung, Optimalisasi Penyelesaian Tunggakan Uang Pengganti Yang Diputus Berdasarkan Undang-Undang Nomor 3 Tahun 1971 Tentang Pemberantasan Tindak Pidana Korupsi. Jakarta: Miswar, 2016.

Sunggono, Bambang. Metode Penelitian Hukum. Jakarta: Raja Grafindo Persada, 2001

Pardede, Rudi. Proses Pengembalian Kerugian Negara Akibat Korupsi, Yogyakarta: Genta Publishing, 2016

\section{Artikel}

Ade Mahmud. "Dinamika Pembayaran Uang Pengganti Dalam Tindak Pidana Korupsi." Jurnal Hukum. Mimb. Justitia, Desember 2017: Vol. 3, No 2.

Guntur Rambey. "Pengembalian Kerugian Negara Dalam Tindak Pidana Korupsi Melalui Pembayaran Uang Pengganti Dan Denda, Jurnal Ilmu Hukum De Lega Lata." Januari - Juni 2016: Vol. 1, No 1.

I. Munirah. "Pembayaran Pidana Uang Pengganti Dalam Perkara Korupsi," Kanun Jurnal Ilmu Hukum." Agustus 2017: Vol. 19, No 2.

J. K. Hafid Rahman, Indra, Agna Susila. "Pelaksanaan Pembayaran Uang Pengganti Dalam Tindak Pidana Korupsi." Jurnal Varia Justicia, Maret 2016: Vol. 12, No. 1.

Muh. Adenriz Yunus, Diana Lukitasari. “Optimalisasi Esekusi Pidana Uang Pengganti Melalui Pembentukan Satuan Kerja Khusus (Studi Kasus Di Kejaksaan Negeri Surakarta,)."Recidive, September-Desember 2019: Vol. 8, No. 3.

M. M. Mohamad Ginanjar, Dahlan Ali. "Eksekusi Uang Pengganti terhadap Terpidana Korupsi oleh Kejaksaan Tinggi Aceh." Kanun Jurnal Ilmu Hukum, Agustus 2016: Vol. 18, No 2.

\section{Peraturan Perundang-Undangan}

Undang-Undang Nomor 31 Tahun 1999 Tentang Pemberantasan Tindak Pidana Korupsi Sebagaimana Telah Diubah Dan Ditambah Dengan Undang-Undang Nomor 20 Tahun 2001 Tentang Perubahan Atas UndangUndang Nomor 31 Tahun 1999 Tentang Pemberantasan Tindak Pidana Korupsi 